\title{
SACLA - 'N BESKOUING
}

Twee artikels in hierdie uitgawe behandel twintigste eeuse sosiologiese en politieke filosofie (of religie?). In die aanloop tot SACLA van 5 tot 15 Julie in Pretoria het talle kritici op praktiese gronde die doel en onderneming as ' $n$ front van die ,linkse" aanslag op Suid-Afrika afgewys. Vir sommige „rool"-WRK-profete (vgl. drs. H. M. Matter van die GKN in G.W) was die opset by verre nie links genoeg nie.

Die redakteur van Woord en Daad (Aug. 1979) pleit in 'n baie ewewigtige inleidingsartikel dat SACLA nie op praktiese gronde nie, maar prinsipiëel geweeg moet word. Hy sê o.a. dat vele deelnemers vir die eerste keer met geloofsgenote oor volksgrense kon verkeer; „emosionele ervarings" van hande vashou ens. is egter nog nie die lewe nie; in S.A. bestaan 'n behoefte aan gesonder gesindhede gebasseer op 'n gemeenskaplike Christelike Belydenis; SACLA mag dui op 'n eventuele polarisering tussen kerk en wêreld, gelowige en ongelowige; 'n Christelike organisasie kan nie tegelykertyd „niekerklik" en tog „,kerk" wees nie ('n Roomse dwaling wat in huidige horisontalisering en versosialisering van die kerklike roeping voorkom); die taak van die „kerke" is om „, in die SA situasie.... relevant die Woord te bedien' 'terwyl die Christene waar nodig gesamentlik politieke, ekonomiese, militêre en ander vraagstukke moet aanpak; kerklike vernuwing in S.A. is eers moontlik wanneer die Bybelse grondslae van die kerk weer opgediep word. „Die antwoord lê nie in sekulêre organisasie, hoe Christelik hulle intensie mag wees, om die taak van die kerke oor te neem nie. As daar 'n probleemgebied ontwaar word waarop Christene stelling moet inneem, moet bestaande of nuwe organisasies dit doen as organisasies, nie as semi- of kwasi-kerk nie.

Die lyne wat prof. J. H. Coetzee so as nie-teoloog trek, is teologies verantwoord. In die GKN is na-oorlogs besin oor die „taak van die kerk" met die gevolg dat die kerk as instituut hoogsgeselekteerd, gemanipuleerd en verengd betrokke geraak het by die sosio-politieke program van die WRK soos dr. J. M. Vorster aantoon. Tereg het o.a. Velema al gewys dat so 'n kerk uiteraard agterryer van die politieke partye moet word omdat die partye die taak eenvoudig beter kan doen. Te lank het Nederlanders en Afrikaners ,kerk" slegs as „instituut" verstaan en die eintlike kerk, die gelowiges of "organisme", weer tot "leke" gedegradeer. Die roeping om sout en lig binne in die wêreld in al sy geledinge te wees, het die predikante as clerus, gemonopoliseer en gemanipuleer. Tereg wys Coetzee dat bestaande organisasies (bv. politieke partye, liefdadigheids- en ander instellings) deur Christene deursuur moet word. Indien dit daartoe lei dat dominees op hulle kategese, prediking en pastoraat sal moet toespits om Christene vir hulle taak bekwaam te makk, kan ons gerus die prys betaal en die heillose weg van die GKN (vgl. verwysings na Verkuyl, Wiersinga e.a. elders in die uitgawe) misloop. 


\section{DIE VALSE PROBLEMATIEK VAN KERK EN WERELD}

Dit het mode geword om ,kerk" en ,wêreld" teenoor mekaar te stel. Gereformeerdes praat klakkeloos agterna. Dit dui dikwels op ' $n$ magstryd om die samelewing te beheers waarin politici en kerkleiers, partye en kerkvergaderings soos die „witch doctor and the king" (Ann Rand) teenoor mekaar te staan kom.

Gedurende die Middeleeue het Rome (met Platoniese dualisme) homself as universele kerk (gees) teenoor die laer wêreld of imperium van die keiser (stof) geïnstitusionaliseer. Calvyn se leer dat God sy eer ontvang wanneer mondige gelowiges God se Woord en Gees op alle terreine uitdra, het nooit werklik die mas opgekom nie. Predikante en sinodes het dikwels die hardste gekeer omdat dit hulle sou uitskakel. Hulle het liewer eie organisasies of partye langs bestaandes gestig om te kan diktcer. Dat politici, ekonome, akademici ook die kerk van Christus kan wees, is skynbaar aksiomaties uitgesluit. So word „kerk" (kerkleiers) en „wêreld" (politici) teenoor mekaar gestel. Dit definieer SACLA as "leiersbyeenkoms". Ondergetekende het vir Woord en Daad (Aug. '79) 'n prognose probeer opmaak.

\section{METODISTIESE EN GESEKULARISEERDE HERKOMS}

Die patroon waarop SACLA aangedien word, appèlleer juis tot daardie kerklike kringe en kerklike leiers in Suid-Afrika wat in hulle jeug met die revivalisme, CSV, kinderkranse, sendingbonde en later met die idee van 'n wêreldwye Christen-ekumene begeester was. Dit is ewe bekend dat die wêreldsekretaris van die internasionale CSV, J. R. Mott en die Sendingkonferensies van die twintigste eeu die teelaarde was waaruit die WRK in 1948 gebore is.

Die metodistiese sendinggenootskappe, Bybelgenootskap, Sondagskool-vereniging, CSV e.a. het altyd 'n beroep gedoen op hulle interkerklikheid, social gospel en tegelykertyd hulle super-kerklikheid. Eie aan die liberalisme van die negentiende eeu het hulle geroem in Christendom bo geloofsverdeeldheid. Hierdie metodistiese sekulêre verenigings het vir hulle self ongenooid een of ander kerklike taak as operasieveld gekies. Hulle het dan ongevraagd werk wat die Skrif aan die gemeente van die Here opdra, oorgeneem. So het die Sendinggenootskappe buite die kerk om sending gedoen; Sondagskoolvereniging buite die kerk om gekatkiseer; die CSV buite die kerk om bekeringswerk, prediking en pastoraat gedoen en in "kringe" geinstitusionaliseer. Talle van hierdie metodistiese buitekerklike vereniginge wat die taak van die kerk kom doen het, wou pragmaties aanvaar word. Die doel sou eenvoudig die middel heilig. Die kerke moes beleefd terugstaan dat hierdie metodistiese organe kerkwerk oorneem.

Die propaganda waarmee SACLA gefloteer word, kom uit dieselfde grond op. SACLA beroep hom andermaal op sy interkerklikheid, sy eenheid bo geloofsverdeeldheid, sy pretensie om geestelik aan te bied wat die kerke nie kan doen nie. SACLA beloof alreeds vanuit 'n kader van aangematigde superkerklikheid dat hy die weg 
vir die kerke in Suid-Afrika sal aanwys. Hy pretendeer om „kerk” te wees.

\section{ONBYBELSE BESKOUING}

Die Skrif beskryf die plurale gemeentes wat onder toesig van ouderlinge as ordelike, geinstitueerde kerke in eenheid van geloof en lewe, gehoorsaam aan die Skrif en Gees, bestaan. Elke gemeente is, vir sover daardie mense hulle na die Woord van Christus gedra, die een onverdeelde liggaam of kerk van die Here Jesus op daardie plek. Anders gesê: die een, wêreldwye (universele) gemeente van ware gelowiges in Jesus Christus is op aarde aanwesig waar gelowiges in 'n gemeente op 'n bepaalde plek die Woord van God suiwer preek en gehoorsaam, die sakramente suiwer bedien en ontvang en volgens die Bybel in alles gedissiplineer word (Calvyn). Die plurale gemeentes staan mekaar as geïnstitueerde kerke in die kerkregering ook in een kerkregeringseenheid (populêr sinodale eenheid genoem) by. Die liggaam van Christus is egter nie die optelsom van gemeentes nie.

Hierdie Bybelse kerkbeeld is gedurende die Middeleeue gesentraliseer in een of ander gesaginstelling: 'n pous of konsilie. Luther se kerkopvatting was gebaseer op sy bekende twee ryke-leer. Vir Luther het die universele kerk onsigbaar tot die ryk (regering) van die hemel (Christus) behoort. In die aardse ryk of bedeling is daar egter 'n sigbare kerkinstituut wat preek om die ware geloof te werk en te versterk. Die kerkinstituut is dus van aardse, tydelike orde en hoef daarom nie ernstig opgeneem te word nie (soos SACLA ook doen).

Die liberalisme van Rousseau het die Lutherse sekularisasie van die kerk verder gevoer. Die kerk is die gevolg van 'n „sosiale kontrak" deur 'n vereniging van gelykgesinde individue met gemeenskaplike godsdiensbelange. Hierdie „kerk” is gevolglik vereenselwig met die sinode as die hoogste liggaam wat die wet en wil vir die hele gemeenskap uitdruk. Die liggaam van Christus kom in hierdie abstrakte idee as „kerk" of "sinode-eenheid" na vore. Volgens hierdie beskouing verwesenlik menslike organisasie in ekumeniese lig. game en sinode-eenhede die bede van Christus in Joh. 17:21 „dat hulle een mag wees soos U Vader in My ..." Uit hierdie bodem kom gedurende die twintigste eeu 'n fanatisme vir ekumeniese organisasies en organisatoriese eenhede na vore wat pretendeer dat hulle die liggaam van Christus vergestalt. Die kerk is dus nie één voordat die mense hom tot één georganiseer het nie.

\section{EENHEID BELANGRIKER AS KERK}

Gepaard met die universalisme van die sosialisme en kommunisme het die „eenheid van die kerk” die „kerk” as doel vervang. Nie meer evangelisasie nie, maar strukturele vergestalting van die "eenheid van die kerk" en aktuele mundiale ,involvement" het normatief geword. Dit verklaar die ontstaan van die WRK, SARK, WARC en die behoefte van SACLA waarin Christene uit die N.G. en andere kerke in 'n „eenheid" saamgetrek word. Die eenheids- 


\section{In die Skriflig}

organisasies word dus tot op groot hoogte met die liggaam van Christus (one body of Christ) vereenselwig en juis daarom as 'n superkerklikheid ten opsigte van die "kleiner en verdeelde" kerke aangedien. Stilswyend identifiseer dit hom met Christus en sy gesag.

Tweedens word hierdie universalisme vanuit die kerkbeeld fanaties toegepas op die sosio-politieke werklikheid. Op sterkte daarvan word gesê dat God geen kulturele, nasionale, etniese, historiese, afstamming en ander assosiasies wil nie. Afsonderlike gemeenskappe is sonde. God wil een universele mensheid (kerk). Dit word nie gesê in watter taal of kultuur die eenheid sal opgaan nie. In die Weste kan aangeneem word dat die Engelse taal en kultuur die ou Roomse Latyn sal verplaas. Ekonomies sluit die universalisme aan by die strewe na 'n wêreldgemeenskap op Marxistiese of neoMarxistiese model. Dit val op dat feitlik elkeen van die buitelandse geldelike donateurs van SACLA hulle steun saam met Marxistiese instansies aan die "bevrydingsorganisasies" soos die PF, SWAPO en ANC in Suidelike Afrika toegesê het. SACLA val dus skynbaar in hulle smaak.

\section{METODISTIESE SKYNHEILIGHEID}

Niemand wil ' $n$ bepaalde deelnemer aan SACLA van skynheilig. heid beskuldig nie. Die „strukturele" skynheiligheid het my egter onlangs tydens die WARC-konferensie opgeval. Die sg. eenheid van die kerk word as model vir die sosio-politieke inrigting van die staat geneem en die Regering daarmee gekonfronteer. Die ironie is egter dat die „kerke" wat die „eenheid" poneer selfs binne dieselfde kerklike familie nog geen eenheid het of kon bewerkstellig nie. Die NGKA waaruit ds. S. Buti, die NG Sendingkerk waaruit dr. A. Boesak en die RCA waaruit ds. Mannikam die ,one undivided South Africa" met een parlement voorskryf, vorm self nie eers „een NG Kerk" of geintegreerde ,swart” gemeentes nie. Dieselfde geld vir die afsonderlike Presbiteriaanse Kerke. 'n Mens kan dergelike "Christenleiers" moeilik ernstig opneem wanneer hulle die een liggaam van Christus, die universele kerk, 'n allesbeheersende dogma vir sosio-politieke eenheid maak, maar dit kerklik net beoefen wanneer hulle gesamentlike politieke verklarings uitreik.

\section{PRETENSIE VAN SUPER-KERK}

Onder die opskrif „Vrae en Antwoorde" beweer SACIA-nuus dat SACLA die gevolg is van "Christengemeenskap" in Nairobi 1976; dat hulle saam kom om "na die Woord van God tot die Kerk in Suid-Afrika te luister" (sic': enkelvoud Kerk); dit gebeur in „vocling met die Kerk" (sic); SACLA wil "hoor wat die Gees deur die aanwesiges aan die Kerke in Suid-Afrika wil sê (Kerk met 'n hoofletter); SACLA wil dat „blootstelling aan die Liggaam van Christus korrektiewe aan die Kerk van Suid -Afrika kan bring".

Hierdie laaste uitspraak verraai onbetwisbaar die identifikasie van SACLA met die universele kerk van ons belydenis, die heilige algemene Christelike Kerk en tegelyk die super- en supra-kerklike 
pretensie waarmee SACLA saamgeroep is. SACLA het hom by voorbaat 'n bepaalde profetiese of apostoliese gerigtheid op die SuidAfrikaanse kerklike, politieke en maatskaplike situasie aangematig. Hy sal paternalisties en kanoniek voorskryf aan die kerke. Dit sou seker moeilik sonder 'n bepaalde sosio-politieke stellingskeuse by die organiseerder beoog kon word.

Die doelstellinge van die SACLA-byeenkoms was sodanig dat enigiemand seker daarop kon reken om sy bepaalde verwagting te verwesenlik. Ek glo dat mense uit kringe van die NGK en AGS wat met die ,revivals" groot geword het, hoë verwagting van evangeliese vroomheid en spesiale ervaring gekoester het.

Andermaal vra 'n mens jou af: Waarom gaan dit eintlik in SACLA? Om Christus en die evangelie? Om ' $n$ bepaalde front van die WRK se betrokkenheid vir 'n "sustianable and just society" of om die daarstelling van SACLA as 'n soort ,alternatiewe gemeenskap" (Bosch) teenoor die Suid-Afrikaanse kerklike, politieke en sosiale werklikheid? Cassidy stel hulle oogmerke egter duidelik wanneer hy sê: „Die hoofbestanddele van die Evangelie moet gestalte kry binne die huidige Suid-Afrikaanse omstandighede. Ons sal nodig hê om die boodskap van SACLA te anker in Suid-Afrikaanse bodem. Anders sal ons gevaar loop om vasgevang te word in 'n nuttelose en irrelevante oefenlopie" (SACLA-nuus p.3).

Voor SACLA byeengekom het weet Cassidy dus al wat die ,boodskap van SACLA" sal wees. Dit is ook duidelik dat hy hom eerder op Suid-Afrika as op die heerskappy van Christus deur sy Woord en Gees in leer en lewe rig. Enige universele Christelike resultate is by voorbaat as nutteloos en irrelevant bestempel. Die gekompromiteerdheid van SACLA aan 'n bepaalde ekumenistiese en ' $n$ bepaalde sosio-politieke bestel vir Suid-Afrika is onbetwisbaar duidelik.

\section{DIE RASSISTIESE ONDERTOON}

Wanneer mense wit en swart as hulle norme neem om die SuidAfrikaanse werklikheid te beoordeel, neem hulle 'n rassistiese vertrekpunt en bly hulle mense diskriminerend volgens ras groepeer. SACLA-nuus (April 1979) steek dan ook van wal met „Volstoom vir Swart betrokkenheid”. Dit word sonder meer beweer: „Die getuienis van die kerk in Suid-Afrika het die Swart Christene dikwels gefaal. Sal SACLA bloot nog 'n oefening in futiliteit wees, leë woorde..." God word ook dogmaties aan die kant van SACLA geannekseer: „Die buitengewone beweging van samehorigheid wat tans plaasvind, is 'n duidelik bewys dat GOD met SACLA is". Die implikasie van hierdie norm is duidelik: „God is aan die kant van „samehorigheid". Die veelgeroemde „samehorigheid" word egter teenstrydig in „Blanke” en "Swart” kompartemente onderskei.

'n Mens besef dat behoud van die dialektiek van wit en swart vir alle Marxiste en neo-Marxiste van essensiële belang is om 'n klasindeling op maklik onderskeibare gronde te handhaaf. Gevolglik verbaas dit nie dat versigtig aangedui word dat die "swart" pool by voorbaat skepties staan oor die moontlike "futiliteit" wat SACLA 
mag oplewer nie. Die ,blanke" pool word dus al gekondisioneer. Biskop Manas Buthelezi verwag dan ook van SACLA die „oplossing van ons land se probleme"; die bekende politieke biskop Tutu, sekretaris van die SARK, wat tradisioneel op Anglikaanse wyse kerk en staat struktureel verbonde sien, verwag dat SACLA ,'n keerpunt in die lewe van Kerk en Staat in Suid-Afrika (sal) wees".

Indien SACLA dus 'n sukses wou wees, moet dit voldoening gee aan die rassisties opgestelde "swart" pool terwyl met geen ander identifiserende realiteite gereken word nie. Die onderliggende eenheidsnoemer by Buthelezi, Tutu, Zulu, e.a. is tog dat hulle met die universele kerk rekening hou; hulle eie plurale kerklike identiteit op volstruispolitieke manier ontken; gevolglik slegs 'n gedenasionaliseerde eenheidstaat voorstaan waarin ' $n$ willekeurige mensemeerderheid, desgewens met 'n rasnoemer getel, alle minderhede sal regeer. Daarmee het SACLA m.i. 'n duidelike sosio-politieke stellingname gedoen.

\section{'N PERSOONLIKE KONKLUSIE}

Kritici van SACLA sal maklik by voorbaat geëtiketteer word as onverskillig teenoor "swart" aspirasies, Tobia's en Sanballats wat die bouwerk van die „one, undivided, just, sustainable society" van die WRK met blatante rassisme wil verongeluk.

In Tegniek het iemand op 'n keer beweer dat die Afrikaner (en Calviniste?) verwag dat die linkse rewolusionêre opmars in die vorm van ' $n$ bokskonfrontasie sal verloop. In werklikheid word dit met die Oosterse judo-tegniek van stapel gestuur. Jy oorwin jou teenstander deur sy eie geld, organisasie, simpatieë en ekumeniese kantore in diens van jou strewe te neem.

Wat 'n mens van SACLA gelees en gesien het, skep die vrees dat dit met sy besondere betrokkenhede, buitelands en binnelands, 'n Trojaanse perd kan word. Daar is immers in vooruitsig gestel dat SACLA op plaaslike vlak deur "getuienis" sal uitwerk en deur "streekstrukture" in stand gehou sal word. Die strukture sal daarop uit wees om ,''n geografiese grens, 'n rassegrens of 'n denominasionale grens" oor te steek (SACLA-nuus, p. 4). Iemand het die mooi beeld gebruik dat linkse organisasies graag vandag bruikbare organisasies „kaap" soos terroriste vliegtuie kaap. 'n Mens moet verwag dat SACLA of sy voortgette streekstrukture 'n begeerlike doelwit vir ekumenistiese sosio-politieke kapers uit die klimaat van die WRK sal wees. 